\title{
The Proteinase Activated Receptor-2 (PAR-2) Mediates Mitogenic Responses in Human Vascular Endothelial Cells

\author{
Molecular Characterization and Evidence for Functional Coupling to the Thrombin Receptor
}

\author{
Humayun Mirza, Victoria Yatsula, and Wadie F. Bahou \\ Department of Medicine, State University of New York at Stony Brook, Stony Brook, New York 11794-8151
}

\begin{abstract}
Proteolytically cleaved receptors, typified by the functional thrombin receptor (TR), represent a novel class of receptors that mediate signaling events by functional coupling to $\mathbf{G}$ proteins. Northern blot analysis completed with a human proteinase activated receptor-2 (PAR-2) cDNA as probe demonstrated the $\sim 3.5 \mathrm{~kb}$ PAR-2 transcript in total cellular RNA from human umbilical vein endothelial cells (HUVEC). Microspectrofluorimetry using Fura2-loaded HUVEC demonstrated a dose-dependent elevation in intracellular calcium transients $\left(\left[\mathrm{Ca}^{2+}\right]_{\mathrm{i}}\right)$ to murine PAR ${ }^{39-44}$ (SLIGRL, putative neoligand after cleavage), with an $\sim \mathrm{EC}_{50}$ of 30 $\mu \mathrm{M}$, and evidence for homologous desensitization with complete recovery at $45 \mathrm{~min}$. Xenopus oocytes microinjected with TR cRNA failed to respond to $200 \mu \mathrm{M} \mathrm{PAR}^{39-44}$, and TR-targeted antisense oligonucleotides specifically abrogated thrombin-induced but not $\mathrm{PAR}^{39-44}$-mediated $\left[\mathrm{Ca}^{2+}\right]_{i}$, excluding the possibility that TR/PAR-2 cell-surface coexpression was structurally linked. HUVEC incubated with PAR $^{39-44}$ demonstrated a dose- and time-dependent mitogenic response similar to that seen with thrombin or $\mathrm{TR}^{42-47}$ (TR-activating peptide, SFLLRN). Preactivation of HUVEC with either PAR ${ }^{39-44}$ or thrombin resulted in heterologous desensitization to the corresponding agonist, an effect that was mediated primarily by TR internalization as evaluated by immunofluorescence and quantitative ELISA. These results ascribe a previously unrecognized function to the PAR-2 receptor, imply that a natural enzyme agonist may circulate in plasma, and suggest the presence of an additional regulatory mechanism controlling receptor activation events in vascular endothelial cells. (J. Clin. Invest. 1996. 97:1705-1714.) Key words: G-proteins • cell signaling • calcium • desensitization • seven-transmembrane receptors
\end{abstract}

\section{Introduction}

Within the G-protein-coupled family of receptors, a novel mechanism of activation has been identified with the isolation

Address correspondence to Dr. Wadie F. Bahou, Division of Hematology, HSCT15-040, State University of New York, Stony Brook, NY 11794. Phone: 516-444-2059; FAX: 516-444-7530.

Received for publication 4 October 1995 and accepted in revised form 16 January 1996.

J. Clin. Invest.

(C) The American Society for Clinical Investigation, Inc.

0021-9738/96/04/1705/10 \$2.00

Volume 97, Number 7, April 1996, 1705-1714 and cDNA cloning of the functional thrombin receptor $(\mathrm{TR})^{1}$ (1). This receptor, a member of the seven-domain transmembrane group of receptors has subsequently been identified on platelets (1), endothelial cells (2), and vascular smooth muscle cells (3) (cells known to be activated by thrombin and intimately associated with hemostatic properties of the vessel wall). A model for thrombin receptor activation in which the serine protease thrombin binds to an acidic hirudin-like domain and proteolytically cleaves the amino terminal exodomain of the thrombin receptor between $\mathrm{Arg}^{41}$ and $\mathrm{Ser}^{42}$ (4) has since been postulated. This irreversible cleavage reveals a new amino terminus that functions as a "tethered ligand," presumably binding intramolecularly to other receptor domain(s) to effect downstream receptor coupling events $(1,4,5)$. Synthetic peptidomimetics, based on the new amino terminus created after cleavage, function as full agonists for receptor activation, bypassing the need for proteolytic receptor activation (1, 6-8). Elucidation of receptor domains involved in ligandmediated receptor activation have been identified in this and other laboratories $(9,10)$.

Proteases play a critical role in mediating cellular migration and invasion by effecting cellular matrix interactions. For example, proteolysis regulates trophoblast implantation, embryomorphogenesis, tissue remodeling, and angiogenesis (11). Furthermore, the regulation of tumor metastases involves a fine balance between protease activation and inhibition. Serine proteases $(12,13)$ such as uPA (urokinase-type plasminogen activator) have been closely linked to metastatic potential (14-16) via direct effects on connective tissue barriers, and intracellular proteases have been implicated as important regulators of apoptosis (17). Recently, the concept that serine proteases may have direct cellular effects has also gained recognition. For example, plasmin and coagulation Factor XIIa are known to activate directly certain cell types $(18,19)$. Likewise, thrombin displays profound actions at the cellular level (20) that are more completely characterized (21-24). For instance, thrombin displays mitogenic potential for vascular smooth muscle cells $(25,26)$, fibroblasts $(27)$, and other mesenchyme-derived cells (27-29); although the ability of thrombin receptor-activating peptides to recapitulate all of thrombin's known cellular effects remains controversial (9, 30 31). Thus, whereas TR-specific peptide ligands display mitogenic effects on vascular smooth muscle cells (26), responses in other cell types are incompletely reproduced, suggesting the presence of alternative receptors or coupling mechanisms (24, 32-36).

The identification of the proteinase-activated receptor-2 (PAR-2) (37) reinforced the concept that circulating proteases

1. Abbreviations used in this paper: HUVEC, human umbilical vein endothelial cell; MBSH, modified Barth's solution; PAR-2, proteinase activated receptor-2; TR, thrombin receptor. 
may effect cellular events through such proteolytically cleaved receptors. Like the thrombin receptor, PAR-2 is activated by proteolytic cleavage, and by synthetic peptide(s) corresponding to the new amino terminus after cleavage. Whereas trypsin clearly activates this receptor, the presence of additional physiological enzyme activator(s) has been postulated $(37,38)$. Although PAR-2 tissue-specific mRNA expression has been demonstrated in the intestine, kidney, stomach, and eye (37), the particular cell types that express PAR-2 have yet to be identified and the apparent tissue specificity may partially reflect the abundance of vascular smooth muscle or endothelial cells.

We now report the presence of PAR-2 on human vascular endothelial cells, and ascribe a previously unrecognized function for this receptor, demonstrating that it mediates endothelial cell proliferative responses when activated by its specific peptide ligand. Furthermore, evidence is presented that functional responses in the form of cross-regulatory mechanisms exist between the thrombin receptor and PAR-2. These data suggest that a natural PAR-2 enzyme agonist may circulate in plasma, mediating, among other functions, proliferation of endothelial cells, and that coexpression of both proteolytically cleaved receptors on endothelial cells may represent a previously unrecognized molecular mechanism regulating thrombin-mediated hemostatic properties of the vessel wall.

\section{Methods}

Reagents. Purified human $\alpha$-thrombin $(\sim 3,500 \mathrm{U} / \mathrm{mg}, 1 \mathrm{nM} \sim 0.1 \mathrm{U} /$ $\mathrm{ml}$ ) was kindly supplied by Dr. J. Jesty (State University of New York at Stony Brook). The thrombin receptor-activating peptide $\mathrm{TR}^{42-47}$ (SFLLRN) and the generation and characterization of the thrombin receptor-specific polyclonal antibody anti-TR ${ }^{1-160}$ have been previously described (24). The peptide ligand representing the new amino terminus of murine PAR-2 (SLIGRL, PAR ${ }^{39-44}$ ) and a second peptide, in which the first two residues were exchanged (LSIGRL), were synthesized using t-boc chemistry on an automated synthesizer (model 430A; Applied Biosystems, Inc., Foster City, CA) as COOHterminal amides with acetylated $\mathrm{NH}_{2}$ termini and purified by reversephase HPLC. Oligonucleotides were synthesized on a single channel synthesizer (Applied Biosystems, Inc.); oligonucleotides used for antisense experiments were specifically synthesized as phosphorothioate derivatives to minimize rapid degradation by cell-specific endonucleases, and the $T_{m}$ calculated to ensure affinity to target RNA sequences at $37^{\circ} \mathrm{C}$. All oligonucleotides used for antisense experiments were evaluated for homology to preexisting genes using the BLAST homology search program and the current version of the GenBank database (39). Restriction enzymes were purchased from Stratagene (La Jolla, CA) and Fura2/AM was purchased from Molecular Probes, Inc. (Eugene, OR). Alkaline phosphatase-conjugated and phycoerythrin (PE)-conjugated goat anti-rabbit IgG (heavy and light chain specific) were purchased from Jackson ImmunoResearch Labs., Inc. (West Grove, PA).

Northern blot analysis. A murine PAR-2 cDNA fragment known to be contained within the large second exon $(37,40)$ was directly isolated from a murine genomic library (Clontech, Palo Alto, CA) by PCR using the following oligonucleotide primers: PAR1746 (5'-3':TCTTATTGGCAGATTAGAAA, nucleotides 336-353) and PAR1572 (5'-3': CACGAATTCACAAAGGGGTCTATGCAGCT, nucleotides 1234-1215 with an engineered EcoRI site [underlined] to facilitate cloning). This PCR fragment was excised as a discrete fragment from a low-melting agarose gel, radiolabeled by random hexamer priming using $\left[{ }^{32} \mathrm{P}\right] \mathrm{dCTP}$, and used to screen a human umbilical vein endothelial cell (HUVEC) cDNA library cloned into the bacteriophage $\lambda \mathrm{gt} 11$, essentially as previously described (41). Three distinct, overlapping cDNA inserts were isolated and their identity to the recently identified human PAR-2 homologue (42) was confirmed by restriction analysis and limited sequence analysis. An $\sim 2.4$-kb EcoRI fragment known to contain the open reading frame was cloned into pBluescript (Stratagene) for Northern analysis. More extensive description and characterization of the human PAR-2 cDNA will be described elsewhere. For Northern blot analysis, confluent HUVECs were directly harvested with a rubber policeman and total cellular RNA was isolated by immediate solubilization in guanidine hydrochloride and serial ethanol precipitation, all as previously described (40). Blots were washed to low $(0.1 \times$ SSC $[1 \times$ SSC is $150 \mathrm{mM}$ sodium chloride and $15 \mathrm{mM}$ sodium citrate, $\mathrm{pH} 7.0$ ], 0.5\% SDS, $1 \mathrm{mM}$ EDTA $\mathrm{pH} 8.0,10 \mathrm{mM}$ sodium phosphate at $55^{\circ} \mathrm{C}$ for $\left.30 \mathrm{~min}\right)$ or high $(0.1 \times$ SSC, $0.1 \%$ SDS, $1 \mathrm{mM}$ EDTA, $\mathrm{pH} 8.0$ and $10 \mathrm{mM}$ sodium phosphate at $68^{\circ} \mathrm{C}$ for $1 \mathrm{~h}$ ) stringency, and analyzed by autoradiography using XAR-5 film (Eastman Kodak Co., Rochester, NY) with an intensifying screen at $-80^{\circ} \mathrm{C}$ for $3-10 \mathrm{~d}$.

Endothelial cell mitogenesis assays. HUVEC were isolated from pooled primary cultures of human umbilical veins as previously described (43), and used in passages two to five. Cells were grown on gelatin-coated plates in M199 supplemented with $10 \%$ FCS, $100 \mu \mathrm{g} /$ $\mathrm{ml}$ endothelial cell growth factor (Collaborative Research Inc., Bedford, MA), $100 \mu \mathrm{g} / \mathrm{ml}$ porcine intestinal heparin, penicillin (100 U/ $\mathrm{ml})$, streptomycin $(100 \mu \mathrm{g} / \mathrm{ml})$, and amphotericin $(5 \mu \mathrm{g} / \mathrm{ml})$. For mitogenesis assays, HUVEC were plated in 96-well clusters (tissue culture-treated polystyrene; Falcon Labware, Lincoln Park, NJ) at an initial density of 10,000 cells/well and grown to confluence by incubation at $37^{\circ} \mathrm{C}$ in complete medium for $48 \mathrm{~h}$. Cells were growth arrested using serum-free M199 supplemented with $1 \mu \mathrm{g} / \mathrm{ml}$ insulin, $5 \mu \mathrm{g} / \mathrm{ml}$ transferrin, and $5 \mu \mathrm{g} / \mathrm{ml}$ selenium (MITS) as previously described (26, 43) and propagated for specified time periods $\left(48\right.$ or $72 \mathrm{~h}$ ) at $37^{\circ} \mathrm{C}$ with the addition of various agonists to study proliferation. At appropriate time points, cells were washed twice with PBS and cell number was determined using a tetrazolium-based colorimetric assay for cell survival and proliferation (Promega Corp., Madison, WI) as previously described (43). This assay is dependent upon the reduction of the tetrazolium salt 3-(4,5-dimethylthiazole-2-yl)-2,5-diphenyltetrazolium bromide (MTT) by the mitochondrial dehydrogenase of viable cells to form a blue formazan product, which is directly measured by an ELISA (44). Briefly, cells were washed twice with PBS and 15 $\mu l$ of the dye solution containing the MTT salt were added to each well in the 96-well microtiter plate. Cells were then incubated at $37^{\circ} \mathrm{C}$ for $4 \mathrm{~h}$, followed by the addition of $100 \mu \mathrm{l}$ of the solubilization/stop solution to individual wells, and the OD of individual wells determined at $550 \mathrm{~nm}$ in an ELISA plate reader (Molecular Devices Corp., Menlo Park, CA) after an overnight incubation. Background ODs at $650 \mathrm{~nm}$ were deducted from OD $550 \mathrm{~nm}$ and actual cell number was calculated by fitting to a standard curve using known amounts of cells simultaneously plated as controls.

Monitoring of cytosolic calcium concentration ( $\left.\left[\mathrm{Ca}^{2+}\right]\right)$. Confluent cells were propagated on glass coverslips and exposed to serumfree medium 2-4 before functional evaluation. Cells were subsequently loaded with $3.0 \mu \mathrm{M}$ Fura2/AM for $60 \mathrm{~min}$ at $37^{\circ} \mathrm{C}$, rinsed with PBS, incubated in Krebs-Henseleit bicarbonate buffer supplemented with $5 \mathrm{mM}$ Hepes, and placed in a Leiden temperature-controlled chamber (Medical Systems Corp., Greenvale, NY) for analysis using a dual-excitation delta scan microspectrofluorimeter (Photon Technologies International, Trenton, NJ). Measurements of fluorescence intensity were performed at a rate of 20 points/s and the ratio of 340: 380 was used to calculate $\left[\mathrm{Ca}^{2+}\right]_{\mathrm{i}}$, applying Fura2/AM calcium standards as previously described (45).

Experiments using antisense oligonucleotides to specifically downregulate the TR were completed as outlined above, except that, upon reaching confluence, HUVECs were incubated with $10 \mu \mathrm{M}$ of individual oligonucleotides for $16-18 \mathrm{~h}$ in MITS at $37^{\circ} \mathrm{C}$ before functional evaluation.

Oocyte injections and $\mathrm{Ca}^{2+}$ measurements. Functional studies were completed using microinjected Xenopus laevis oocytes and in vitro 
transcribed TR cRNA, essentially as previously described (9). After frog dissection, Dumont-stage V/VI oocytes were washed and incubated overnight at $18^{\circ} \mathrm{C}$ in modified Barth's solution (MBSH: 82.5 $\mathrm{mM} \mathrm{NaCl}, 2.5 \mathrm{mM} \mathrm{KCl}, 1 \mathrm{mM} \mathrm{CaCl} 2,1 \mathrm{mM} \mathrm{MgCl}, 5 \mathrm{mM}$ Hepes, $\mathrm{pH}$ 7.8) without $\mathrm{Ca}^{2+}$, supplemented with penicillin $100 \mathrm{U} / \mathrm{ml}$ and streptomycin $100 \mu \mathrm{g} / \mathrm{ml}$. The following day, oocytes were microinjected with TR cRNA, and subsequently incubated at $18^{\circ} \mathrm{C}$ in MBSH for $48 \mathrm{~h}$. For functional evaluation, oocytes were washed in $\mathrm{Ca}^{2+}$-free $\mathrm{MBSH}$, and pools of 30 oocytes were loaded in the same buffer for $4 \mathrm{~h}$ at $18^{\circ} \mathrm{C}$ with $50 \mu \mathrm{Ci} / \mathrm{ml}$ of ${ }^{45} \mathrm{Ca}^{2+}$. Healthy oocytes (seven per well) were transferred to six-well clusters in $0.5 \mathrm{ml} \mathrm{MBSH}$ and extensively washed to obtain steady state calcium efflux measurements. After activation by individual agonists, $0.5 \mathrm{ml}$ of solution was removed (and replaced by a similar volume) at 10 min intervals for scintillation counting. The ${ }^{45} \mathrm{Ca}^{2+}$ release ratio was defined as the cpm released during the steady-state 10-min interval.

Immunofluorescence staining and ELISA. For immunofluorescent staining, confluent HUVEC in eight-well-chamber slides were activated with individual agonists for a period of $5 \mathrm{~min}$ (or left inactivated), washed with PBS five times and then fixed in $4 \%$ paraformaldehyde (for determination of cell-surface staining) for $20 \mathrm{~min}$ at $25^{\circ} \mathrm{C}$ or fixed and permeabilized using ice-cold $100 \%$ acetone for $60 \mathrm{~s}$. Fixed HUVECs were then extensively washed with PBS, followed by incubation with $300 \mu \mathrm{g} / \mathrm{ml}$ anti-TR ${ }^{1-160}$ in PBS for $60 \mathrm{~min}$ at $4^{\circ} \mathrm{C}$. Cells were washed with PBS three times and incubated with the PE-conjugated goat anti-rabbit antibody at 1:200 dilution in PBS for $60 \mathrm{~min}$ at $4^{\circ} \mathrm{C}$. After a final wash with PBS five times cells were mounted in Aquamount (Lerner Lab, Stamford, CT) and fluorescent images were obtained using a Diaphot (Nikon Inc., Melville, NY) inverted microscope equipped with fluorescent optics (Nikon Inc., Garden City, NY). Images were frame-averaged to 256 frames with Image I software (Universal Imaging Corp., Media, PA) using laser light excited at $529 \mathrm{~nm}$ and a blocking filter of $550 \mathrm{~nm}$.

An ELISA was developed for quantification of cell-surface thrombin receptor expression. Briefly, 10,000 endothelial cells were aliquoted into individual 96-well microtiter plates, and propagated until confluent, usually within 48 to $72 \mathrm{~h}$. Cells were then washed with PBS and incubated with individual agonists (without agonists in controls) in serum-free M199 for a period for $5 \mathrm{~min}$. Subsequently, they were washed in PBS and fixed in 4\% paraformaldehyde for $15 \mathrm{~min}$ at $25^{\circ} \mathrm{C}$. After fixation, the cells were washed in PBS and incubated with $1 \%$ BSA at $4^{\circ} \mathrm{C}$ for 90 min to eliminate nonspecific binding. Cells were then incubated with anti-TR ${ }^{1-160}$ at a dilution of 1:1000 in PBS
$\underline{\mathbf{K b}}$

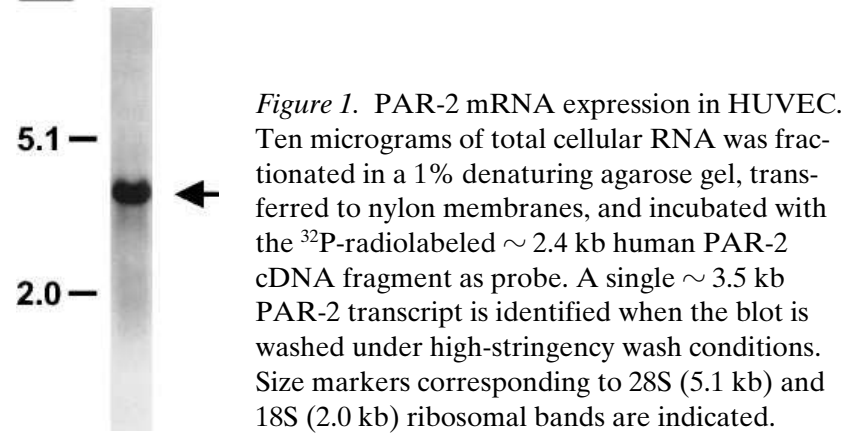

for $4 \mathrm{~h}$ at $4^{\circ} \mathrm{C}$, washed with PBS three times and incubated with the alkaline phosphatase-conjugated goat anti-rabbit antibody at a final dilution of 1:5,000 in PBS for $60 \mathrm{~min}$ at $4^{\circ} \mathrm{C}$. (In preliminary experiments, we observed no differences in anti-TR ${ }^{1-160}$ binding when thrombin-stimulated wells were washed in a buffer containing hirudin, which was subsequently omitted from further experiments.) After a final thorough wash with PBS, $100 \mu \mathrm{l} /$ well of alkaline phosphatase substrate solution $(1 \mathrm{mg} / \mathrm{ml} p$-nitrophenylphosphate in $0.1 \mathrm{M}$ diethanolamine buffer $\mathrm{pH}$ 10.4) was added and the relative intensity of the color reaction was quantified using an ELISA plate reader at $405 \mathrm{~nm}$.

\section{Results}

Characterization of the PAR-2 receptor on human vascular endothelial cells. Since proteases are abundantly present in plasma and exhibit cellular actions, we postulated that PAR-2 may be expressed on vascular endothelial cells. We initially sought to establish the presence of a PAR-2-specific mRNA transcript using endothelial cell RNA. Oligonucleotide primers encompassing a portion of the murine PAR-2 cDNA known to be contained within the large second exon $(37,40)$ were used to directly amplify an $\sim 900$ bp PCR fragment from a murine genomic library. The PCR product revealed a single band of the appropriate size as judged by agarose gel electro-

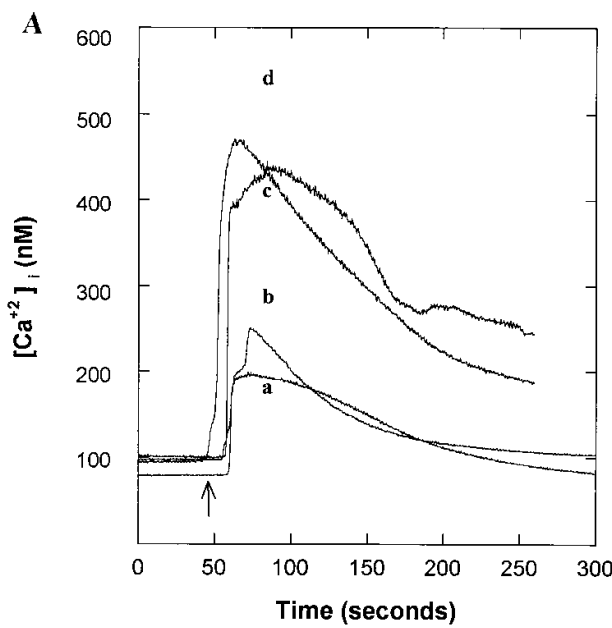

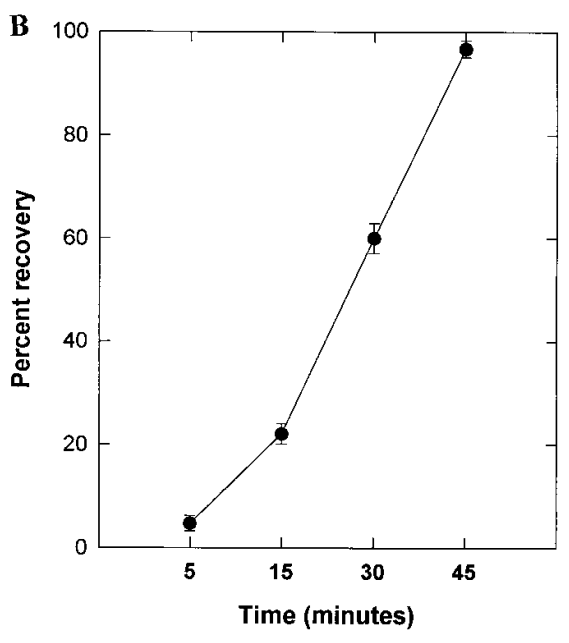

Figure 2. Functional $\mathrm{PAR}^{39-44}$ responses in HUVEC. HUVEC were propagated on gelatin-coated coverslips until confluent, loaded with 3.0 $\mu \mathrm{M}$ fura2/AM for 60 minutes at $37^{\circ} \mathrm{C}$, and $\left[\mathrm{Ca}^{2+}\right]_{\mathrm{i}}$ monitored by microspectrofluorimetry. In $(A)$ cells were activated with $5 \mu \mathrm{M}$ (curve $a$ ), $20 \mu \mathrm{M}$ (curve $b$ ), $40 \mu \mathrm{M}$ (curve $c$ ), or $80 \mu \mathrm{M}$ (curve $d$ ) $\mathrm{PAR}^{39-44}$. No responses were evident using $200 \mu \mathrm{M}$ LSIGRL (not shown). In $B$, cells were preactivated with $40 \mu \mathrm{M}$ peptide, washed and then reactivated at various time points with the same concentration of the peptide. $\mathrm{PAR}^{39-44}$ resulted in a dose-dependent elevation in $\left[\mathrm{Ca}^{2+}\right]_{i}$, and displayed homologous desensitization with full recovery at $45 \mathrm{~min}$. These results are representative of a single set of experiments, completed in triplicate. 


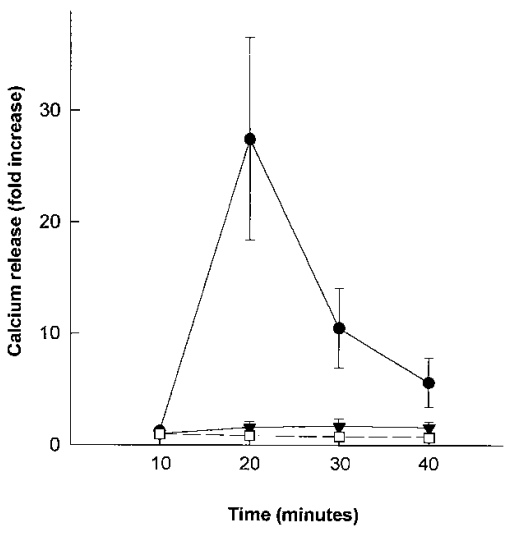

less than $300 \mathrm{cpm}$ per $10 \mathrm{~min}$ from all wells. All points represent the mean \pm the SEM of at least five wells from a single representative set of experiments. PAR ${ }^{39-44}$ scrambled control (LSIGRL) at concentrations up to $200 \mu \mathrm{M}$ also failed to result in any ${ }^{45} \mathrm{Ca}^{2+}$ release (not shown). $\bullet$, thromin; $\mathbf{\nabla}, 100 \mu \mathrm{M} \mathrm{PAR}^{39-44} ; \square, 200 \mu \mathrm{M} \mathrm{PAR}^{39-44}$.

phoresis and its identity was confirmed by extensive restriction analysis. This murine fragment was then used to isolate a human PAR-2 cDNA from an endothelial cell library and its identity to the human homologue (42) was confirmed by extensive restriction analysis and partial sequence analysis. As demonstrated in Fig. 1, this radiolabeled insert demonstrated the presence in HU-VEC of a distinct mRNA transcript of $\sim 3.5 \mathrm{~kb}$, essentially identical in size to its murine homologue (37), confirming that the PAR-2-specific transcript is expressed in this cell type. No additional cross-hybridizing fragments were seen under low stringency wash conditions.

To further characterize functional expression of this receptor on HUVEC, a 6-mer PAR-2 peptide corresponding to the neoligand after cleavage (SLIGRL, PAR ${ }^{39-44}$ ) was used to study cell activation by microspectrofluorimetry. As shown in Fig. 2, activation of HUVEC with $\mathrm{PAR}^{39-44}$ peptide ligand resulted in a rapid rise of intracytosolic calcium transients. These responses were concentration dependent with an $\mathrm{EC}_{50}$ for activation approximating $30 \mu \mathrm{M}$. Because of previous evidence for homologous desensitization of the TR when preactivated with either thrombin or its peptide ligand $(2,46,47)$, we evaluated whether a similar mechanism existed for this receptor. Ligandmediated activation followed by restimulation of the cells demonstrated an attenuated response (at $5 \mathrm{~min}$ ) approximating $25 \%$ of the initial peak response seen with nascent cells (Fig. 2 B). Recovery of peak cellular responses to PAR ${ }^{39-44}$ was gradual and time dependent such that full recovery was evident at $45 \mathrm{~min}$. The homologous desensitization and recovery to the PAR-2 peptide ligand in HUVEC is not dissimilar to the same phenomenon studied using thrombin receptor-specific peptide ligands $(46,47)$.

Specificity of the PAR-2 ligand for its receptor. Data presented previously $(2,24)$ and outlined above collectively confirm that vascular endothelial cells coexpress both proteolytically cleaved receptors described to date. To exclude the possibility that PAR ${ }^{39-44}$-induced activation events could be mediated by cross-activation of the TR, functional expression studies were completed in Xenopus laevis oocytes. As demonstrated in Fig. 3, Xenopus oocytes microinjected with TR cRNA exhibited a brisk ${ }^{45} \mathrm{Ca}^{2+}$ release when activated with $10 \mathrm{nM}$ thrombin, es- sentially as described previously (9). In sharp contrast, oocytes failed to respond when activated with $\mathrm{PAR}^{39-44}$ at concentrations up to $200 \mu \mathrm{M}$, well above those identified as being sufficient for receptor activation.

The PAR-2 receptor functions as a mediator of endothelial cell proliferation. Various proteases have displayed mitogenic potential for different cell types $(19,48)$, and thrombin and its peptide ligand are mitogenic for vascular smooth muscle cells (26). The ability of $\mathrm{PAR}^{39-44}$ to induce mitogenesis in HUVEC was subsequently investigated. As evident in Fig. 4, $\mathrm{PAR}^{39-44}$ produced a proliferative response which was noticeable at progressive concentrations of the agonist and sustained at 48 and $72 \mathrm{~h}$. Peak responses appeared evident at a concentration of $100 \mu \mathrm{M} \mathrm{PAR}^{39-44}$. The functionally inactive ligand LSIGRL failed to induce any proliferative response at $72 \mathrm{~h}$. This response to $\mathrm{PAR}^{39-44}$ was then compared to the proliferative potential of $10 \mathrm{nM}$ thrombin and $100 \mu \mathrm{M} \mathrm{TR}^{42-47}$, concentrations which produce maximal increases in $\left[\mathrm{Ca}^{2+}\right]_{\mathrm{i}} \mathrm{HUVEC}(24)$. As illustrated in Fig. $4 \mathrm{~B}, 100 \mu \mathrm{M}$ PAR $^{39-44}$ produced a mitogenic response in HUVEC that was nearly $60-70 \%$ of the maximal response produced by $10 \%$ serum. This response was strikingly similar to that produced by saturating concentrations of thrombin or its agonist peptide $\mathrm{TR}^{42-47}$.

$P A R-2$ receptor is functionally coupled to the thrombin receptor on HUVEC. Functional coupling within the same receptor family has been previously described $(49,50)$ in muscarinic and adrenergic receptors in the form of cross-regulation. Previously, we also observed homologous desensitization of the PAR-2 receptor after stimulation by its peptide ligand agonist (Fig. $2 \mathrm{~B}$ ). The coexpression of both proteolytically cleaved receptors on endothelial cells allowed us to further investigate the existence of functional receptor cross-regulation. As shown in Fig. 5, HUVEC's response to $10 \mathrm{nM}$ thrombin, af-

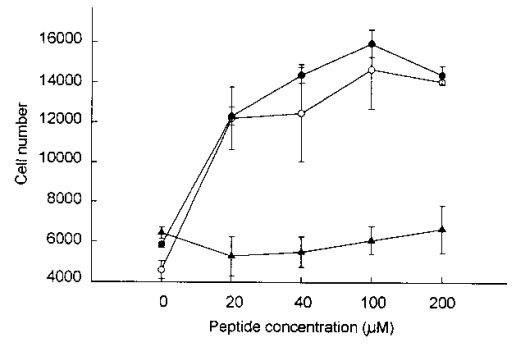

Figure 4. Mitogenic responses in HUVEC. HUVEC were detached using $0.05 \%$ trypsin $0.2 \%$ EDTA, resuspended to $1.0 \times 10^{5}$ cells/ml, and $100 \mu \mathrm{l}$ $\left(1.0 \times 10^{4}\right.$ cells $)$ were plated into individual wells of a 96-well microtiter plate for a minimum of $48 \mathrm{~h}$ in complete media. Cells were then washed and incu-

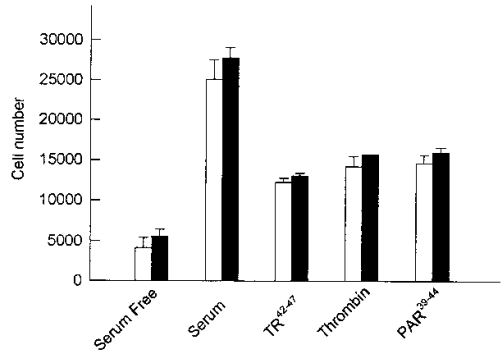
bated with varying concentrations of $\mathrm{PAR}^{39-44}$ in MITS or the inactive peptide (LSIGRL) for 48 or $72 \mathrm{~h}$ prior to evaluation of proliferative responses as outlined in Methods (top). In the bottom, experiments were completed in an identical manner except that agonists used included $10 \%$ serum, 100 $\mu \mathrm{M} \mathrm{TR}^{42-47}, 10 \mathrm{nM}$ thrombin or $40 \mu \mathrm{m} \mathrm{PAR}{ }^{39-44}$. All results are expressed as the mean \pm the SEM from six individual wells of a representative set of experiments. $(A) \bigcirc, 48$ hours; $\bullet 72$ hours; $\boldsymbol{\Delta}$ LSIGRL 72 hours. $(B) \square, 48$ hours; $\square, 72$ hours. 

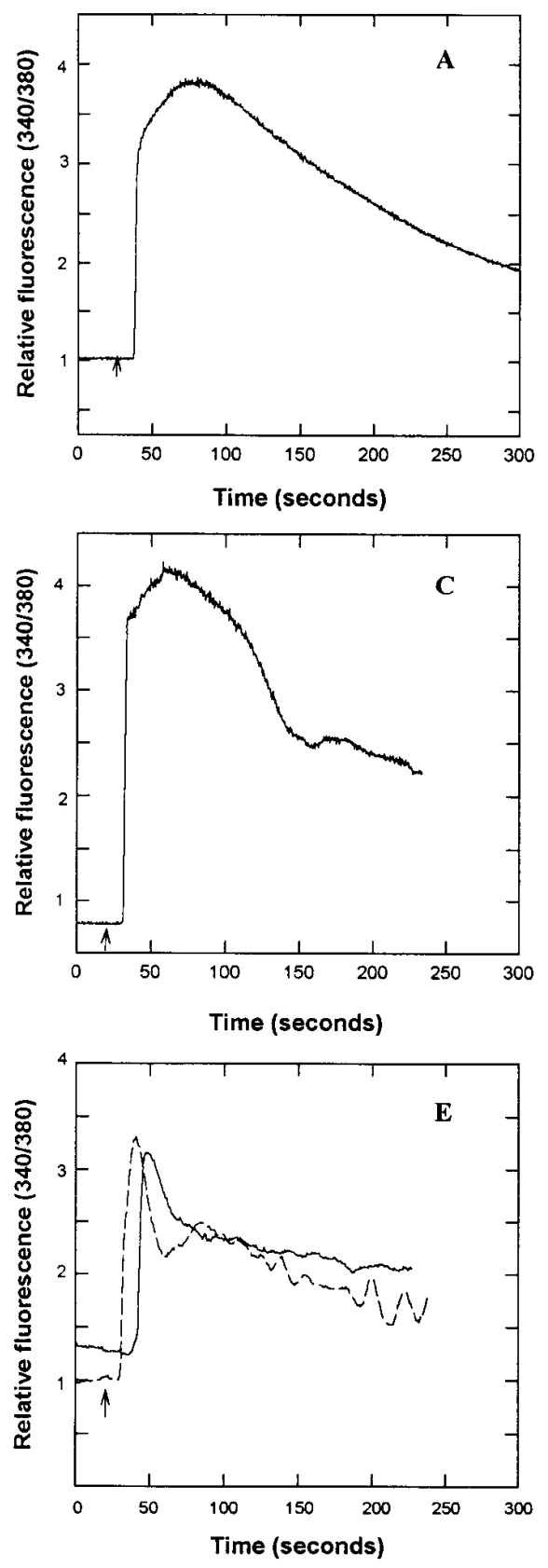
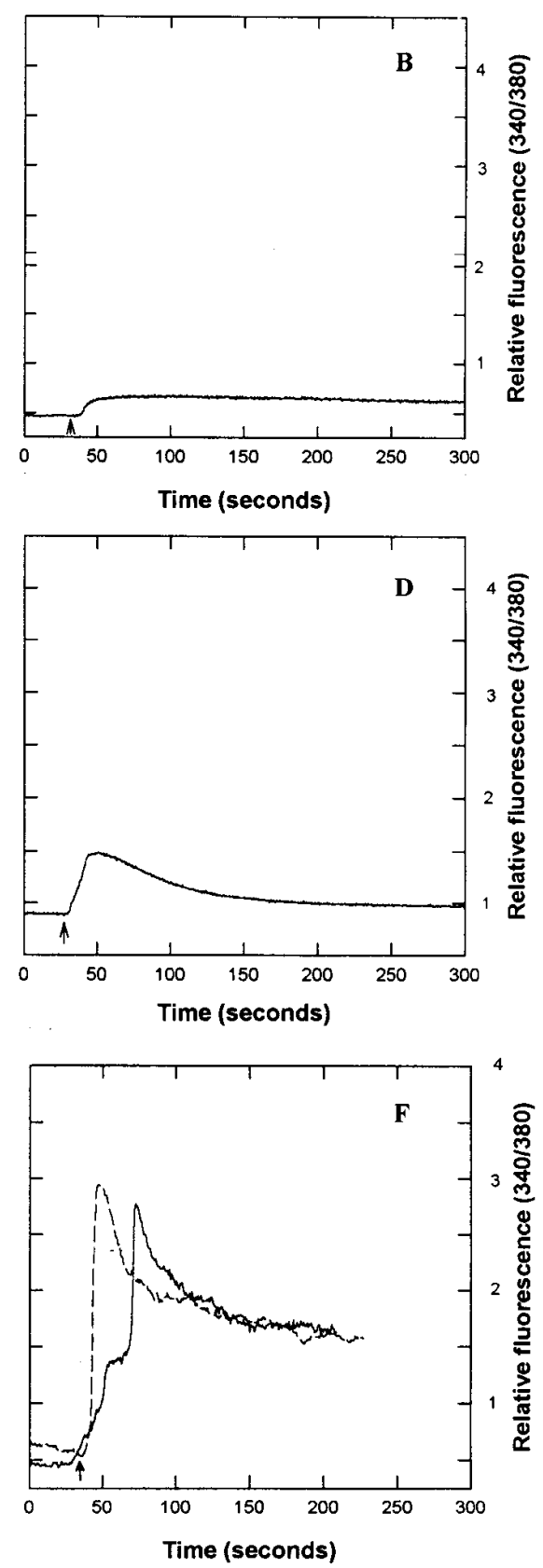

Figure 5. TR/PAR-2 heterologous desensitization in HUVEC. Microspectrofluorimery was completed essentially as outlined in Methods. A and $C$ represent responses to $10 \mathrm{nM}$ thrombin nad $40 \mu \mathrm{M} \mathrm{PAR}^{39-44}$. In $B$, cells were preactivated with $40 \mu \mathrm{M}$ $\mathrm{PAR}^{39-4}$, washed with PBS and then reactived 5 min later with $10 \mathrm{nM}$ thrombin. In $D$, after preactivation with $10 \mathrm{nM}$ thrombin, cells were washed and reactivated 5 min later with $40 \mu \mathrm{M} \mathrm{PAR}^{39-44}$. $E$ and $F$ represent cells treated in a similar manner, and activated with $10^{-9} \mathrm{M}$ bradykinin, (solid curves, nascent responses) or preactivated with 10 $\mathrm{nM}$ thrombin $(E)$ or $40 \mu \mathrm{M} \mathrm{PAR}^{39-}$ ${ }^{44}(F)$, followed by $10^{-9} \mathrm{M}$ bradyki$\operatorname{nin}$ (dashed curves). ter prior activation by $40 \mu \mathrm{M} \mathrm{PAR}^{39-44}$, was profoundly reduced in comparison to thrombin responses seen in previously inactivated (nascent) cells. Similarly, HUVEC demonstrated an attenuated response to $\mathrm{PAR}^{39-44}$ after initial activation by $10 \mathrm{nM}$ thrombin. To exclude the possibility of a nonspecific effect secondary to intracellular coupling events or depletion of a common intracellular $\mathrm{Ca}^{2+}$ pool, the effect of bradykinin on intracytosolic calcium transients was studied before and after activation of cells with thrombin or $\mathrm{PAR}^{39-44}$. The bradykinin receptor(s) is similarly known to be a member of the sevendomain transmembrane group of receptors and is coupled to phospholipase $\mathrm{C}$ in endothelial cells (51). As illustrated in Fig. $5 E$ and $F$, activation of HUVEC by $10^{-9} \mathrm{M}$ bradykinin induced a rise in intracytosolic $\mathrm{Ca}^{2+}$ essentially identical to that seen in cells preactivated by either $10 \mathrm{nM}$ thrombin or $40 \mu \mathrm{M}$
$\mathrm{PAR}^{39-44}$. Similar results were obtained using $10^{-6} \mathrm{M}$ endothelin-1, with responses of nascent cells being similar to responses seen from cells preactivated by thrombin or $\mathrm{PAR}^{39-44}$ (not shown).

The molecular mechanism of thrombin receptor desensitization in endothelial cells has been previously studied with evidence for receptor internalization $(46,47)$ playing a prominent regulatory role. To further investigate the mechanism of heterologous downregulation of the TR by $\mathrm{PAR}^{39-44}$, immunofluorescence staining using a TR-specific antibody was completed. As illustrated in Fig. 6, nascent nonpermeabilized cells demonstrated intense rim staining, signifying the presence of the thrombin receptor on the HUVEC cell surface. In contrast, immunofluorescent images of permeabilized cells exhibited dense intracellular staining, consistent with the presence 

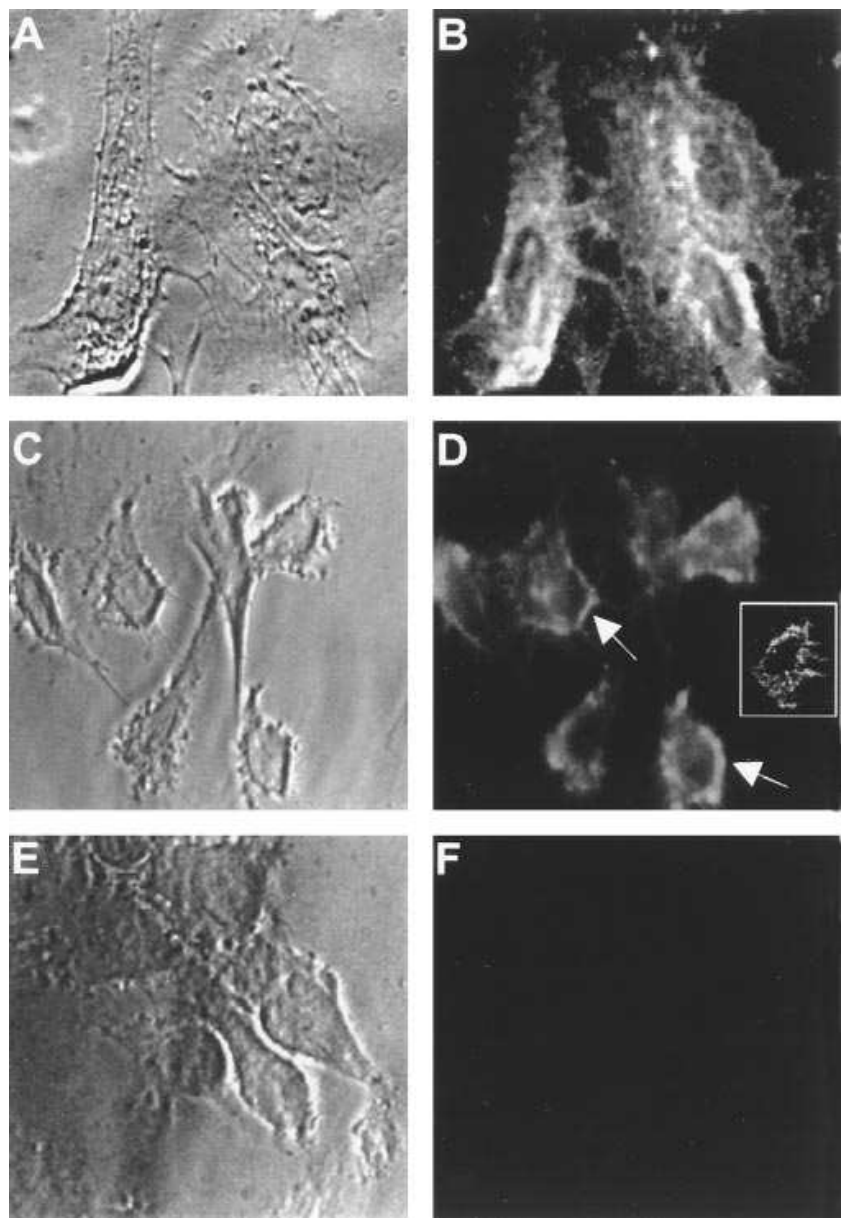

Figure 6. Immunofluorescence staining of HUVEC. Cells were grown until confluent, serum-starved for $2 \mathrm{~h}$, and then fixed and permeabilized using ice-cold acetone for $60 \mathrm{sec}(B)$ or fixed without permeabilization using $4 \%$ paraformaldehyde ( $D$ and $F$ ) (prior to immunofluorescence staining using anti-TR ${ }^{1-160}$ ), as outlined in Methods. The corresponding phase-contrast images are displayed in $A, C$, and $E$. Distinct intracellular staining is evident in $B$ while cell-surface staining is seen in non-permeabilized cells $(D)$. The inset demonstrates the typical (doughnut shaped) immunofluorescent pattern reflecting cell-surface staining as confirmed by confocal laser microscopy (magnification 4,500). No staining is seen using the secondary antibody alone $(F)$. Final magnification in all other panels is 2,860 .

of a large intracellular pool of thrombin receptors. These observations are consistent with those previously described (46, 47). In comparison, HUVEC activated with $40 \mu \mathrm{M} \mathrm{PAR}^{39-44}$ demonstrated attenuation of the cell surface staining pattern (Fig. 7), consistent with the removal of TR from the cell surface. Similar activation of HUVEC by $10 \mathrm{nM}$ thrombin yielded the same effect, with diminution of the cell surface staining (Fig. 7 C). Permeabilized HUVEC continued to show the same dense intracellular staining for TR even after activation with $\mathrm{PAR}^{39-44}$ or thrombin, suggesting continued presence of a dense population of intracellular thrombin receptors (Fig. 7, $E$ and $F$ ). Indeed, cells stimulated by either ligand demonstrated the appearance of patchy clumping, most likely reflecting TR internalization to intracellular lysosomal compartments (46, 47). These initial observations were confirmed by quantitative ELISA and are outlined in Fig. 8. HUVEC activated with 10
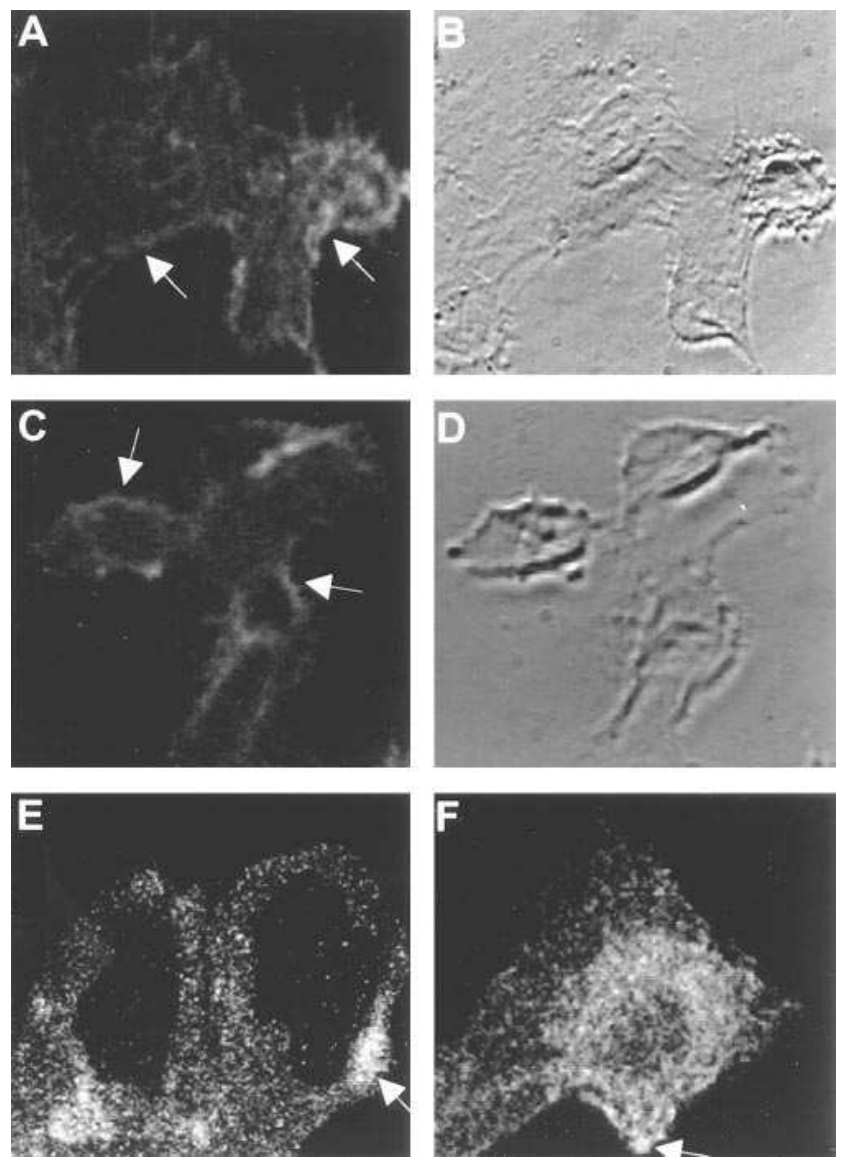

Figure 7. TR internalization after activation-dependent responses. Confluent HUVEC were serum-starved, activated with $40 \mu \mathrm{M}$ $\operatorname{PAR}^{39-44}(A$ and $E$ ) or $10 \mathrm{nM}$ thrombin $(C$ and $F)$, and then fixed with $4 \%$ paraformaldehyde $(A$ and $C$ ) or ice-cold acetone $(E$ and $F)$, prior to immunofluorescence staining using anti-TR ${ }^{1-160}$. The corresponding phase contrast images for $A$ and $C$ are displayed to the right. Preactivation of cells with either agonist results in diminished cell-surface staining (arrows, $A$ and $C$ ), although the intense intracytoplamic staining remains evident. The patchy areas of intense immunofluorescence (arrows, $E$ and $F$ ) presumably reflect TR internalization to endothelial cell-specific lysosomes (46). Final magnification is 2,860.

$\mathrm{nM}$ thrombin or $40 \mu \mathrm{M} \mathrm{PAR}^{39-44}$ demonstrated significantly lower $(P<0.01)$ cell surface immunoreactivity as compared to nascent (inactivated) cells, again consistent with the results seen by immunofluorescent staining. Because the anti-TR $\mathrm{TR}^{1-160}$ antibody recognizes epitopes spanning the entire $\mathrm{NH}_{2}$-terminal extension, the diminished but persistent immunoreactivity evident with either staining or ELISA confirms that a subpopulation of TRs remains cell surface expressed, consistent with previous observations (47).

Thrombin receptor/PAR-2 coexpression are not structurally linked. The demonstration of heterologous desensitization and TR internalization after PAR-2 activation suggested that the functional coupling could be attributable to cell surface physical interactions affecting receptor expression in cells coexpressing both receptors. This possibility was addressed using thrombin receptor-specific antisense oligonucleotides and microspectrofluorimetry in HUVEC. Initially, we targeted three potential sites that may be involved in transcriptional or translational regulation of TR gene expression: 5 '-untranslated re- 


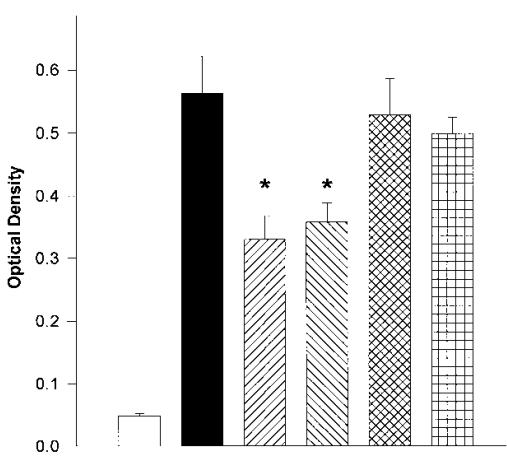

Figure 8. ELISA for evaluation of TR internalization. Endothelial cells were plated at $1.0 \times 10^{4}$ cells/well in complete media, and propagated for a minimum of $48 \mathrm{~h}$ until confluent. Cells were then washed with PBS and incubated with $10 \mathrm{nM}$ thrombin, $40 \mu \mathrm{M}$ PAR $^{39-44}, 1 \times 10^{-9} \mathrm{M}$ bradykinin, $1 \times 10^{-6} \mathrm{M}$

endothelin-1 (without agonists in the controls) in serum-free medium M199 for a period of $5 \mathrm{~min}$. Cells were then washed with PBS $\times 5$, fixed in $4 \%$ paraformaldehyde, and evaluated by ELISA for TR cellsurface expression as outlined in Methods. Cells preactivated by either thrombin or PAR ${ }^{39-44}$ displayed similar diminution of TR surface expression compared to unactivated cells ( $P<0.01$, asterisks). Cells incubated with the secondary antibody alone functioned as controls. These results represent the mean \pm SEM from 6 individual wells. $\square$,

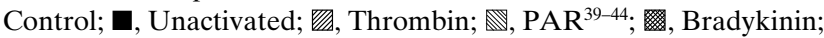
曲, ET-1.

gion, $3^{\prime}$-untranslated region, and the initiator methionine (Fig. 9 A). As evaluated by microspectrofluorimetry using HUVEC, one particular oligonucleotide (TR848) caused a noticeable diminution of peak $\left[\mathrm{Ca}^{2+}\right]_{i}$ when cells were activated by thrombin (Fig. 9 B). This effect was time dependent, displaying a more pronounced inhibition after a 16 -h incubation as compared to the effect seen at four h. Indeed the 4-h response was near maximal, but clearly delayed, suggesting that a threshold number of receptors is required for the development of an immediate and maximal response, consistent with previous studies (52). Neither the sense control nor other oligonucleotides evaluated demonstrated a similar effect (Fig. $9 B$ and not shown). The specificity of TR848 to downregulate the thrombin receptor was confirmed by complementary Northern analysis and quantitative ELISA (Fig. 10). Antisense oligonucleotides were then used to compare functional responses in HUVEC when activated by either thrombin or $\mathrm{PAR}^{39-44}$. As shown in Fig. 11, thrombin-mediated responses were specifically attenuated using TR848, whereas no such effect was seen in identically treated cells activated by $\mathrm{PAR}^{39-44}$. In a similar set of experiments, preincubation of HUVEC with TR848 failed to result in heterologous desensitization to $\mathrm{PAR}^{39-44}$ when cells were preactivated with thrombin (data not shown). These data imply that nonstimulated cells fail to activate regulatory mechanisms (presumably phosphorylation events) that serve as the brake for subsequent reactivation by the $\mathrm{PAR}^{39-44}$ ligand. In summary, these results with antisense oligonucleotides confirm our initial observations establishing the specificity of $\mathrm{PAR}^{39-44}$ for its receptor and further establish that the molecular regulation of TR/PAR-2 cell surface expression occurs as an independent event in cells expressing both receptors.

\section{Discussion}

Proteolytically cleaved seven-transmembrane receptors represent a novel class of cell surface receptors displaying a unique mechanism of activation, with subsequent cell-signaling events mediated by functional coupling to $G$ proteins. Although the
A.

\begin{tabular}{llll} 
Oligonucleotide & Targeted region & Position & Sequence $\left(S^{\prime}-3^{\prime}\right)$ \\
\hline TR847 (A) & 5'-Untransłated & $63-42$ & ACCCTCGGCGAGCGCTGTGTCT \\
TR848 (A) & Initiator MET & $230-211$ & CCCCATTGTCCCGGGCTCTG \\
TR849 (A) & 3'-Untranslated & $1524-1506$ & AACCTCCCAGCAGTCCCTT \\
TR850 (A) & Initiator MET & $236-219$ & CCGCGGCCCCATTGTCCC \\
TR1718 (S) & Initiator MET & $211-230$ & CAGAGCCCGGGACAATGGGG
\end{tabular}

B.

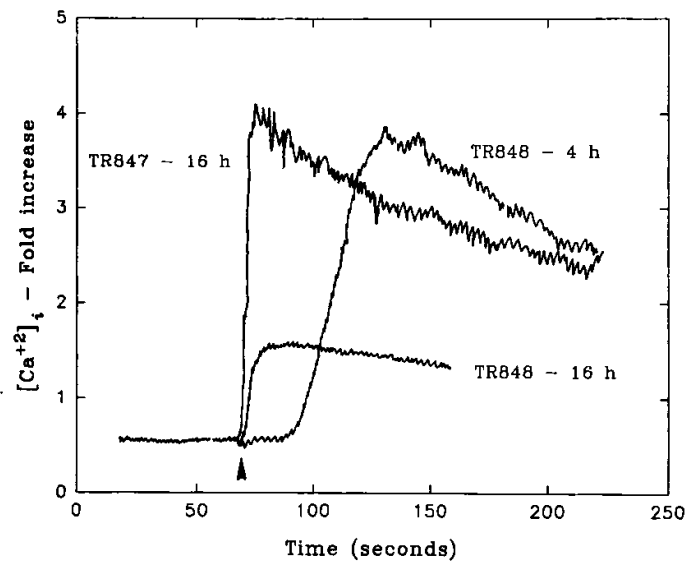

Figure 9. Antisense oligonucleotides used for thrombin receptor-specific down regulation. $(A)$ Nucleotide sequence with position and orientation (A: antisense; $S$ : sense) is indicated. (B) HUVEC were propagated on gelatin-coated coverslips until confluent and then incubated with $10 \mu \mathrm{M}$ of individual oligonucleotides synthesized as phosphorothioate derivatives for indicated times at $37^{\circ} \mathrm{C}$. Cells were then washed and activation-dependent responses to $10 \mathrm{nM}$ thrombin (arrow) were studied by microspectrofluorimetry as outlined in Methods. One oligonucleotide TR848 resulted in a time-dependent attenuation of thrombin responsiveness, with no inhibition seen using any other oligonucleotides studied (not shown). The elevation in $\left[\mathrm{Ca}^{2+}\right]_{\mathrm{i}}$ evident with TR847 is essentially identical to that seen in untreated cells.

cell types that express the prototypic thrombin receptor have been extensively characterized (1-3), little is known about cell-specific expression of PAR-2. Previous work had demonstrated tissue-specific expression of PAR-2 by Northern analysis (37), although functional activity and expression at the cellular level remained uncharacterized. Our data provide convincing evidence at the molecular level that PAR-2 is expressed and functionally active in vascular endothelial cells. Because the PAR-2 -specific physiologic enzyme activator remains unknown, we used the receptor-activating peptide PAR $^{39-44}$ (SLIGRL) as a surrogate marker to demonstrate activation-dependent responses in HUVEC. Thus, although the human homologue has not been isolated, synthetic peptide ligands based on the murine sequence are sufficiently similar to effect activation of human cells known to express PAR-2. Likewise the expression of PAR-2 on endothelial cells suggests that a physiologic protease activator may be a circulating plasma protein.

Previous data had demonstrated that thrombin fails to activate PAR-2 (37), although the ability of TR-specific peptidomimetics to activate this receptor remain incompletely characterized (40). Because of the coexpression of both proteolytically cleaved receptors on vascular endothelial cells, two complementary strategies were adopted to establish the specificity of the PAR-2 ligand for its receptor. Xenopus oocytes 
A
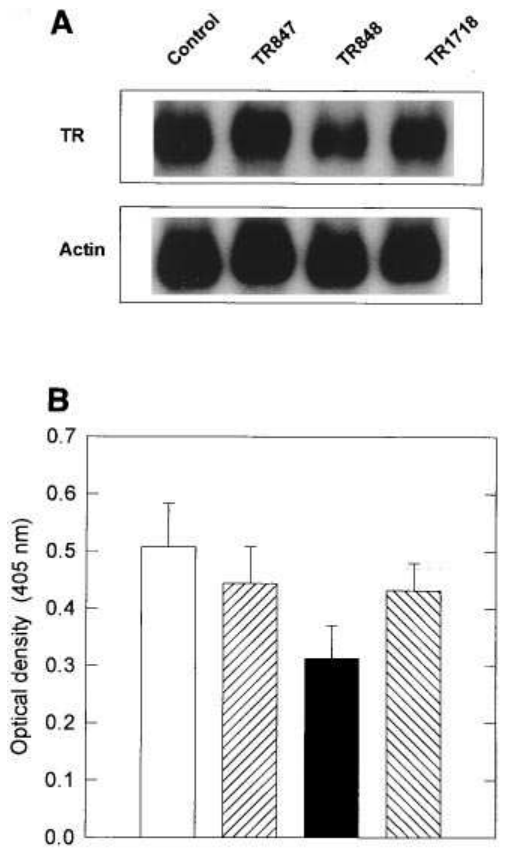

Figure 10. Specificity of TR antisense oligonucleotides. ( $A$ ) HUVEC were incubated in MITS with $10 \mu \mathrm{M}$ of various oligonucleotides (or MITS alone as control) as outlined in Fig. 9 legend, total cellular RNA was harvested, and $10 \mu \mathrm{g}$ of RNA was evaluated by Northern analysis using the ${ }^{32} \mathrm{P}$-radiolabeled TR cDNA as probe for quantification of transcript expression. The blot was then stripped, rehybridized with the human actin cDNA, washed using identical high stringency conditions and evaluated by autoradiography for the identical amount of time (2 d). (B) After preincubation of cells with 10

$\mu \mathrm{M}$ of individual oligonucleotides for $18 \mathrm{~h}$, an ELISA was utilized to quantify relative amounts of TR cell-surface expression using anti$\mathrm{TR}^{1-160}$, as outlined in Methods. Results shown represent the mean \pm SEM from six individual wells. As confirmed both at the mRNA and protein level, preincubation of HUVEC with TR848 resulted in a specific down-regulation of thrombin receptor expression.

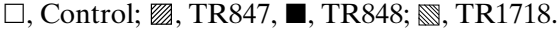

microinjected with the thrombin receptor cRNA were thrombin responsive, but failed to respond to $\mathrm{PAR}^{39-44}$ and in HU-VEC, TR-specific antisense oligonucleotides abrogated thrombin responsiveness, but failed to effect responsiveness to $\mathrm{PAR}^{39-44}$. Thus, these observations establish the specificity of the PAR-2 ligand for its receptor and exclude the possibility that endothelial cell responses are mediated by trans-activation of the TR. Indeed, these observations are consistent with previous TR structure-function studies demonstrating the importance of the phenylalanine in position 2 of the Tr-activating peptide $\left(\mathrm{TR}^{42-47}\right)$ to affect receptor activation (6-8). Furthermore, the inability of TR antisense oligonucleotides to affect $\mathrm{PAR}^{39-44}$-mediated responses excludes the possibility that the cell-surface coexpression of both receptors are physically linked or dually required for optimal activation-dependent responses.

The ability of proteases to induce cellular proliferation has been well described, although only recently appreciated. Thus, tryptase demonstrates mitogenic potential for airway smooth muscle cells (48) and coagulation Factor XII displays mitogenic effects on HepG2 cells (19). Likewise, thrombin is mitogenic for vascular smooth muscle cells (26), fibroblasts (27, 32 ), and other mesenchyme-derived cells (27-29), although the ability of its peptide ligand to mediate mitogenic responses has primarily been demonstrated in vascular smooth muscle cells. Somewhat unexpectedly, the PAR $^{39-44}$ ligand demonstrated a concentration- and time-dependent ability to effect proliferative responses in vascular endothelial cells. Indeed, these re-

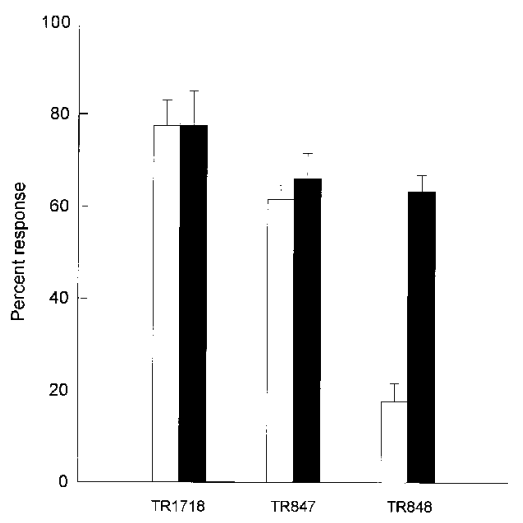

Figure 11. Effect of antisense olionucleotides on cellular responses to individual agonists. HUVEC were propagated and studied as outlined in Fig. 5 legend, prior to activation with $10 \mathrm{nM}$ thrombin or $40 \mu \mathrm{M} \mathrm{PAR}^{39-44}$. No inhibition of PAR $^{39-44}$ mediated responses are evident using any TR-specific oligonucleotides. These results represent the mean \pm SEM

from three individual coverslips $(100 \%$ response is defined as that seen using identically treated coverslips devoid of oligonucleotides). $\square$, Thrombin; $\mathbf{\square}$, PAR $^{39-44}$.

sponses were surprisingly similar to those seen with either thrombin or its peptide ligand $\mathrm{TR}^{42-47}$. Extrapolation of these data further suggests that the PAR-2 physiological enzyme activator will also display mitogenic potential.

Molecular mechanisms regulating thrombin receptor activation and desensitization have been extensively studied and include a combination of receptor internalization and phosphorylation events, (with the former playing a well-characterized role in endothelial cells and the megakaryocytic cell lines HEL and CHRF-288 (46, 47)). For example, homologous downregulation of the thrombin receptor by thrombin (or $\mathrm{TR}^{42-47}$ ) activation has been demonstrated, as well as heterologous downregulation of the thrombin receptor protein by PGE1 and PMA (53). Finally, the role of other proteases such as neutrophil-derived cathepsin $\mathrm{G}$ modulate TR activation by cleavage within a discrete sequence within the $\mathrm{TR} \mathrm{NH}_{2}$-terminal extension (54). Our observations suggest an additional regulatory mechanism for thrombin receptor activation and extend to PAR-2 regulation. The demonstration of heterologous downregulation and internalization of the TR by PAR-2 activation (and the functional evidence for heterologous downregulation of PAR-2 by thrombin) suggest the presence of cross-talk between these two G-protein-coupled receptors. Cross-talk between G-protein-coupled receptors has been previously described between muscarinic and adrenergic receptors and postulated to encompass mechanisms involving receptor phosphorylation and transcriptional cross-regulation $(49,50)$. Whether either of these two mechanisms pertains to the TR/PAR-2 interactions observed in endothelial cells remains undetermined, although the rapid desensitization would be more consistent with a molecular mechanism incorporating intracellular phosphorylation events, possibly regulating the observed TR internalization. Because of the lack of a PAR-2specific antibody, we were unable to further evaluate regulatory events involved in thrombin-mediated PAR-2 desensitization, although we speculate that a similar mechanism involving PAR-2 internalization may be operational.

The similarities between PAR-2 and the TR reinforce the concept of an extended superfamily of proteolytically cleaved receptors that may be involved in cell regulatory phenomena. Like the TR, PAR-2 exhibits activation-dependent homolo- 
gous desensitization with a similar time course of recovery (46) and both receptors display mitogenic responses when activated by their respective peptide ligands. These functional properties also extend to the structural organization of the genes, both of which display minimal complexity and are similarly organized. Genomic analysis has confirmed that both genes contain two exons, that the larger second exons contain the majority of the coding sequences, and that the proteolytic cleavage sites for both receptors are contained within this second exon $(37,41,55)$. Thus, although this proposed gene family is currently limited to two members, data presented in this and previous reports suggest the presence of a larger gene family, potentially displaying complex interactive and regulatory features. Finally, the isolation of a physiological enzyme activator for PAR-2 should help to address whether this receptor/agonist complex may serve as a regulatory mechanism modulating the actions of thrombin on the vessel wall.

\section{Acknowledgments}

We thank Dr. Harold Magazine (Queens College, NY, NY) for assistance with the preparation of peptides, Dr. M. Goligorsky for his insightful comments and Dr. Edward Nord for the guidance and use of the microspectrofluorimeter. We also thank Dr. Sanford Simon for assistance with the ELISA plate reader, Dr. J. Jesty for assistance with preparation of diagrams, and Mrs. Shirley Murray for her excellent assistance in preparation of the manuscript. David Colflesh assisted in the generation of computer-enhanced images.

This work was supported by grants from the American Heart Association, New York State Affiliate and National Institutes of Health R01HL02431.

\section{References}

1. Vu, T., D. Hung, V. Wheaton, and S. Coughlin. 1991. Molecular cloning of a functional thrombin receptor reveals a novel proteolytic mechanism of receptor activation. Cell. 64:1057-1068.

2. Ngaiza, J., and E. Jaffe. 1992. A 14 amino acid peptide derived from the amino terminus of the cleaved thrombin receptor elevates intracellular calcium and stimulates prostacyclin production in human endothelial cells. Biochem. Biophys. Res. Commun. 179:1656-1661.

3. Zhong, C., D. Hayzer, M. Corson, and M. Runge. 1992. Molecular cloning of the rat vascular smooth muscle thrombin receptor. Evidence for in vivo regulation by basic fibroblast growth factor. J. Biol. Chem. 267:16975-16979.

4. Vu, T., V. Wheaton, D. Hung, I. Charo, and S. Coughlin. 1991. Domains specifying thrombin-receptor interaction. Nature (Lond.). 353:674-677.

5. Chen, J., M. Ishii, L. Wang, K. Ishii, and S.R. Coughlin. 1994. Thrombin receptor activation. Confirmation of the intramolecular tethered liganding hypothesis and discovery of an alternative intermolecular liganding mode. J. Biol. Chem. 269:16041-16045.

6. Coller, B.S., P. Ward, M. Ceruso, L.E. Scudder, K. Springer, J. Kutok, and G.D. Prestwich. 1992. Thrombin receptor activating peptides: importance of the $\mathrm{N}$-terminal serine and its ionization state as judged by $\mathrm{pH}$-dependence, nuclear magnetic resonance spectroscopy, and cleavage by aminopeptidase $\mathrm{M}$. Biochemistry. 31:11713-11720.

7. Scarborough, R., M. Naughton, W. Teng, D. Hung, J. Rose, T. Vu, V. Wheaton, C. Turck, and S. Coughlin. 1992. Tethered ligand agonist peptides: structural requirements for thrombin receptor activation reveal mechanism of proteolytic unmasking of agonist function. J. Biol. Chem. 267:13146-13149.

8. Vassallo, R.R., Jr., T. Kieber-Emmons, K. Cichowski, and L.F. Brass. 1992. Structure-function relationships in the activation of platelet thrombin receptors by receptor-derived peptides. J. Biol. Chem. 267:6081-6085.

9. Bahou, W., J. Kutok, A. Wong, C. Potter, and B. Coller. 1994. Identification of a thrombin receptor sequence specifying activation-dependent responses. Blood. 84:4195-4202.

10. Gerstzen, R.E., J. Chen, M. Ishii, K. Ishii, L. Wang, T. Nanevicz, C.W. Turck, T.H. Vu, and S.R. Coughlin. 1994. Specificity of the thrombin receptor for agonist peptide is defined by its extracellular surface. Nature (Lond.). 368: 648-651.

11. Liotta, L.A., P.S. Steeg, and W.G. Stetler-Stevenson. 1991. Cancer metastasis and angiogenesis: An imbalance of positive and negative regulation. Cell. 64:327-336.
12. Reich, R., E. Thompson, Y. Iwamato, G.R. Martin, J.R. Geason, G.C. Fuller, and R. Muskin. 1988. Effects of inhibitors of plasminogen activator, serine proteinases and collagenase IV on the invasion of basement membranes by metastatic cells. Cancer Res. 48:3307-3312.

13. Wang, M., and M.E. Stearns. 1988. Blocking of collagenase secretion by astamustine during in vitro turnover and cell invasion. Cancer Res. 48:62626271

14. Dano, K., P.A. Andreason, J. Grondehl-Hansen, P. Kristensen, L.S. Nielsen, and L. Shriver. 1985. Plasminogen activators, tissue degradation and cancer. Adv. Cancer Res. 44:139-266.

15. Estreicher, A., A. Wohlwend, D. Belin, W.D. Schleuring, and J.D. Vassalli. 1989. Characterization of the cellular binding site for the urokinase-type plasminogen activator. J. Biol. Chem. 264:1180-1189.

16. Axelrod, J.H., R. Reich, and R. Mishkin. 1989. Expression of human recombinant plasminogen activators enhances invasion and experimental metastasis of H-ras-transformed NIH 3T3 cells. Mol. Cell Biol. 9:2133-2141.

17. Martin, S.J., and D.R. Green. 1995. Protease activation during apoptosis: death by a thousand cuts? Cell. 82:349-352.

18. Chang, W.C., G.Y. Shi, Y.H. Chow, L.C. Chang, J.S. Hau, M.T. Lin, C.J. Jen, L.Y. Wing, and H.L. Wu. 1993. Human plasmin induces a receptor-mediated arachidonate release coupled with $\mathrm{G}$ proteins in endothelial cells. Am. J. Physiol. 264:C271-C281.

19. Schmeidler-Sapiro, K.T., O.D. Ratnoff, and E.M. Gordon. 1991. Mitogenic effects of coagulation factor XII and factor XIIa on Hep $\mathrm{G}_{2}$ cells. Proc. Natl. Acad. Sci. USA. 88:4382-4385.

20. Shuman, M.A. 1988. Thrombin cellular interactions. Ann. NY Acad. Sci. 485:228-239.

21. Davey, M.E., and S.R. Luscher. 1967. Actions of thromin and other coagulant and proteolytic enzymes on platelets. Nature (Lond.). 216:857-858.

22. Weksler, B.B., C.W. Ley, and E.A. Jaffe. 1978. Stimulation of endothelial cell prostacyclin production by thrombin, trypsin, and the ionophore A23187. J. Clin. Invest. 62:923-930.

23. Nagy, Z., K. Kolev, E. Csonka, M. Pek, and R. Machovich. 1995. Contraction of human brain endothelial cells by thrombogenic and fibronolytic factors. An in vitro cell culture model. Stroke. 26:265-270.

24. Bahou, W., B. Coller, C. Potter, K. Norton, J. Kutok, and M. Goligorsky. 1993. The thrombin receptor extracellular domain contains sites crucial for peptide ligand-induced activation. J. Clin. Invest. 91:1405-1413.

25. Chaikoff, E.L., R. Caban, C. Yan, and M.S. Runge. 1995. Growthrelated responses in arterial smooth muscle cells are arrested by thrombin receptor antisense sequences. J. Biol. Chem. 270:7431-7436.

26. McNamara, C.A., I.J. Sarembock, L.W. Gimple, J.W. Fenton II, S.R Coughlin, and G.K. Owens. 1993. Thrombin stimulates proliferation of cultured rat aortic smooth muscle cells by a proteolytically activated receptor. J. Clin. Invest. 91:94-98.

27. Glenn, K.C., D.H. Carney, J.W. Fenton, and D.D. Cunningham. 1980 Thrombin active site regions are required for fibroblast receptor binding and initiation of cell division. J. Biol. Chem. 255:6609-6616.

28. Chen, L.B., and J.M. Buchanan. 1975. Mitogenic activity of blood components. I. Thrombin and prothrombin. Proc. Natl. Acad. Sci. USA. 72:131-135.

29. Pohjanpelto, P. 1978. Stimulation of DNA synthesis in human fibroblasts by thrombin. J. Cell. Physiol. 95:189-194.

30. Carney, D.H., R. Mann, W.R. Redin, S.D. Pernia, D. Berry, J.P. Heggers, P.G. Hayward, M.C. Robson, J. Christie, and C.J. Annable, et al. 1992. Enhancement of incisional wound healing and neovascularization in normal rats by thrombin and synthetic thrombin receptor-activating peptides. J. Clin. Invest. 89:1469-1477.

31. Tesfamariam, B., G.T. Allen, D. Normandin, and M.J. Antonaccio. 1993. Involvement of the "tethered ligand" receptor in thrombin-induced endothelium-mediated relaxations. Am. J. Physiol. 265:H1744-H1749.

32. Kim, D.W., F. Wang, S. Ramakrishnan, D.L. Scott, T.M. Hensler, W.C Thompson, and D.H. Carney. 1994. Mouse fibroblasts defective in thrombin mitogenesis possess functional proteolytically activated receptor for thrombin: requirements for a second signaling pathway. J. Cell. Physiol. 160:573-584.

33. Zucker, S., C. Conner, B. DiMassimo, H. Ende, and W. Bahou. 1995 Thrombin induces cell surface activation of gelatinase A in vascular endothelial cells: physiological regulation of angiogenesis. J. Biol. Chem. 270:23730-23738.

34. Vouret-Craviari, V., E. Van Obberghen-Schilling, V. Rasmussen, A. Pavirani, J. Lecocq, and J. Pouyssegur. 1991. Synthetic alpha-thrombin receptor peptides activate $G$ protein-coupled signaling pathways but are unable to induce mitogenesis. Mol. Cell. Biol. 3:95-102.

35. McGowan, E., and T. Detwiller. 1987. Modified platelet responses to thrombin. Evidence for two types or receptors or coupling mechanisms. J. Biol. Chem. 261:739-746.

36. Chambard, J., S. Paris, G. L'Allemain, and J. Pouyssegur. 1987. Two growth factor signalling pathways in fibroblasts distinguished by pertussis toxin. Nature (Lond.). 326:800-803.

37. Nystedt, S., K. Emilsson, C. Wahlestedt, and J. Sundelin. 1994. Molecular cloning of a potential proteinase activated receptor. Proc. Natl. Acad. Sci. USA. 91:9208-9212.

38. Coughlin, S.R. 1994. Protease-activated receptors start a family. Proc. Natl. Acad. Sci. USA. 91:9200-9202. 
39. Pustell, J., and F. Kafatos. 1986. A convenient and adaptable microcomputer environment for DNA and protein sequence manipulation and analysis. Nucleic Acids. 14:479-488.

40. Nystedt, S., A.K. Larsson, H. Aberg, and J. Sundelin. 1995. The mouse proteinase-activated receptor- 2 cDNA and gene. Molecular cloning and functional expression. J. Biol. Chem. 270:5950-5955.

41. Bahou, W., A. Campbell, and M. Wicha. 1992. cDNA cloning and molecular characterization of MSE55: a novel human serum constituent protein that displays bone marrow stromal endothelial cell-specific expression. J. Biol. Chem. 267:13986-13992.

42. Nystedt, S., K. Emilsson, A.-K. Larsson, B. Strombeck, and J. Sundelin. 1995. Molecular cloning and functional expression of the gene encoding the human proteinase-activated receptor 2. Eur. J. Biochem. 232:84-89.

43. Bahou, W.F., C.L. Potter, and H. Mirza. 1994. The VLA-2 (alpha 2 beta 1) I domain functions as a ligand-specific recognition sequence for endothelial cell attachment and spreading: molecular and functional characterization. Blood. 84:3734-3741.

44. Mossman, J. 1983. Rapid colorimetric assay for cellular growth and survival: Application to proliferation and cytotoxic assays. J. Immunol. Methods. 65:55-63.

45. Grynkiewicz, G., M. Poenie, and R.Y. Tsien. 1985. A new generation of $\mathrm{Ca}^{2+}$ indicators with greatly improved fluorescence properties. J. Biol. Chem. 260:3440-3450.

46. Hein, L., K. Ishii, S.R. Coughlin, and B.K. Kobilka. 1994. Intracellular targeting and trafficking of thrombin receptors. A novel mechanism for resensitization of a G protein-coupled receptor. J. Biol. Chem. 269:27719-27726.

47. Woolkalis, M.J., T.M. DeMelfi, Jr., N. Blanchard, J.A. Hoxie, and L.F.
Brass. 1995. Regulation of thrombin receptors on human umbilical vein endothelial cells. J. Biol. Chem. 270:9868-9875.

48. Brown, J.K., C.A. Jones, C.L. Tyler, S.J. Ruoss, T. Hartmann, and G.H Caughey. 1995. Tryptase-induced mitogenesis in airway smooth muscle cells. Potency, mechanisms, and interactions with other mast cell mediators. Chest. 107:95S-96S.

49. Morris, G.M., J.R. Hadcock, and C.C. Malbon. 1991. Cross-regulation between G-protein-coupled receptors. Activation of beta 2-adrenergic receptors increases alpha 1-adrenergic receptor mRNA levels. J. Biol. Chem. 266: 2233-2238.

50. Lee, N.H., and C.M. Fraser. 1993. Cross-talk between $\mathrm{m} 1$ muscarinic acetylcholine and $\beta_{2}$-adrenergic receptors. J. Biol. Chem. 268:7949-7957.

51. Smith, J.A., C. Webb, J. Holford, and G.M. Burgess. 1995. Signal transduction pathways for B1 and B2 bradykinin receptors in bovine pulmonary artery endothelial cells. Mol. Pharmacol. 47:525-534.

52. Ishii, K., L. Hein, B. Kobilka, and S.R. Coughlin. 1993. Kinetics of thrombin receptor cleavage on intact cells. Relation to signaling. J. Biol. Chem. 268:9780-9786.

53. Zacharias, U., Y. Xu, J. Hagege, J.D. Sraer, L.F. Brass, and E. Rondeau 1995. Thrombin, phorbol ester, and cAMP regulate thrombin receptor protein and mRNA expression by different pathways. J. Biol. Chem. 270:545-550.

54. Molino, M., N. Blanchard, E. Belmonte, A.P. Tarver, C. Abrams, J.A. Hoxie, C. Cerletti, and L.F. Brass. 1995. Proteolysis of the human platelet and endothelial cell thrombin receptor by neutrophil-derived cathepsin G. J. Biol. Chem. 270:11168-11175.

55. Bahou, W., C. Potter, and A. Wong. 1992. Molecular characterization of the human thrombin receptor gene. Blood. 80(Suppl. 1):265a. 